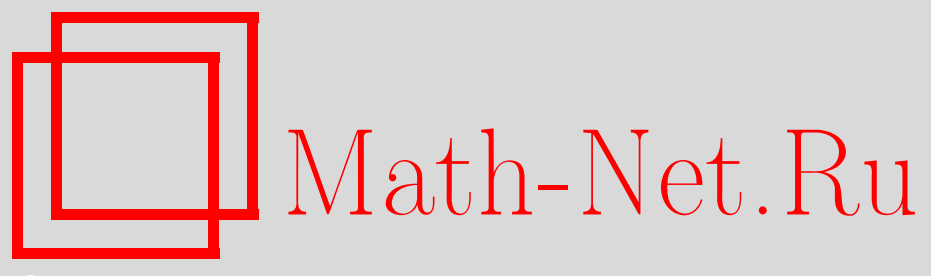

А. М. Вершик, Об Эйлеровском фонде и первом конкурсе имени Эйлера, УМH, 2007, том 62, выпуск 4, 190

DOI: https://doi.org/10.4213/rm7924

Использование Общероссийского математического портала Math-Net.Ru подразумевает, что вы прочитали и согласны с пользовательским соглашением http://www . mathnet.ru/rus/agreement

Параметры загрузки:

IP : 54.164 .48 .24

26 апреля 2023 г., $11: 58: 26$

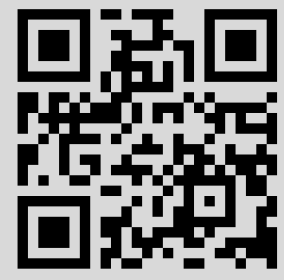




\section{Об Эйлеровском фонде и первом конкурсе имени Эйлера}

Фонд Эйлера организован в порядке подготовки празднования 300-летнего юбилея Леонарда Эйлера в С.-Петербурге, но его цели значительно шире. Учредителями фонда стали Л. Д. Фаддеев, И. А. Ибрагимов, А. М. Вершик и С. В. Востоков, который был выбран президентом фонда (см. http://www.euler-foundation.org).

Основная задача фонда - поддержать молодых ученых, дать им возможность работать в стране, учредить для них стипендии, премии, организовывать научные поездки, а также проводить конференции и т. д. Фонду по мере сил помогли своими пожертвованиями бывшие выпускники матмеха и физфака, ныне ставшие успешными предпринимателями. Их благотворительность носит чисто альтруистический характер и заслуживает самой широкой популяризации, но в целом они захотели остаться анонимами. При их участии фонд помог провести несколько летних математических школ (обычно эти мероприятия проходят за счет энтузиазма организаторов и родительских денег). Фонд провел первую в городе Олимпиаду для учителей математики. Об участии его в подготовке и проведении юбилея Эйлера см. предыдущую статью.

Очень важной инициативой фонда стала организация всероссийского конкурса Фонда Эйлера для студентов, аспирантов и молодых ученых. Первый конкурс был проведен в феврале-мае 2007 г., итоги его были подведены в конце мая, а награждение победителей состоялось 10 июня на эйлеровском фестивале. В конкурсе приняло участие в номинации "Студенты" - 11 человек, в том числе из Москвы - 5, из С.-Петербурга - 3, в номинации "Аспиранты" - 12 человек, в том числе из Москвы - 6, из С.-Петербурга - 2, в номинации "Молодые ученые" (до 35 лет) - 16 человек, в том числе из Москвы - 6, из С.-Петербурга - 3 всего (39 человек). В каждой номинации учреждалось по три премии и произвольное число похвальных отзывов. Победителям присуждались годовые стипендии: за 1-е место соответственно студентам, аспирантам, молодым ученым - 7500 руб., 10000 руб., 12500 руб. в месяц; за 2-е место 5000 руб., 7500 руб., 10000 руб. в месяц; за 3-е место 2500 руб., 5000 руб., 7500 руб. в месяц. В положении о конкурсе особо оговаривалось, что при прочих равных условиях предпочтение получают нестоличные (не из Москвы и С.-Петербурга) конкурсанты, точно так же предпочтение отдается тем, кто не получал аналогичных премий. В жюри конкурса входили А. М. Вершик, С. В. Востоков, С. В. Кисляков и др. Итоги первого конкурса опубликованы на сайте http://www.euler-foundation.org.

A.M. Вершик 